\title{
AN ANALYSIS OF THE TEACHING METHODOLOGY USED FOR THE TEACHING OF ENGLISH IN AN INDONESIAN SENIOR HIGH SCHOOL
}

\author{
M. Junaidi Marzuki \\ Universitas Hamzanwadi, marzuki.mjunaidi@gmail.com
}

\begin{abstract}
The intent of this article is to analyze a theory that informs teacher's classroom practice in daily basis. It also addresses strengths and weaknesses underlying teaching approach deployed and provides areas that need improvement for a more fun, engaging and meaningful learning experience. A single observed and implemented lesson planning on Science \& Technology was analyzed and evaluated. It was found that the pedagogical practice of the class was based on Grammar Translation Method (GTM) and Audio-Lingual Method. Despite this, the use of former approach in the class afforded the students the opportunity to expand their knowledge, was efficient for the teacher, and promoted the students' understanding allowing the use native language. It is suggested, for the refinement of the instruction, that the teacher employ a pair or group work and be creative and innovative in the use of relevant materials, not making the textbook as a legitimate resource for the learning process.
\end{abstract}

Keywords: GTM, Audio-Lingual Method, CLT.

\section{TEACHING CONTEXT}

This critical analysis of English language teaching took place at Senior High School of Muallimin in Lombok, Indonesia. It was one of private all-male schools under the supervision of Minister of Religious Affairs of Republic of Indonesia. There were 35 students in the class, ranging in age from 15 to 18. Most of them were bilinguals as they speak their mother tongue apart from Bahasa Indonesia as an official language. The learners were at a preintermediate to intermediate level. They varied greatly in terms of 
social and economic background, but relatively shared similar beliefs and cultural values.

English was a compulsory subject, and it was intended to prepare students to well perform in the final examination, taking place at the end of each semester. They were 48 meetings in one semester, consisting of two meetings in a week with total of 90 minutes each. Tests were the most common forms of assessment used to evaluate to what extent the goals of the teaching and learning have been achieved, as well as the determining factor whether a student will proceed to the next class level.

In terms of course syllabus type, the teacher used topical syllabus, meaning that a syllabus built on a wide variety of topics, such as education, economy, science and technology, transportation and politics. There were no state-of-the-art teaching facilities, as well as learning resources employed in the classroom except prescribed textbook, blackboard and a box of chalk.

\section{ANALYSIS OF PRACTICE}

Before going further to a critical analysis of teaching practice, this session begins with a brief description of how English teaching practice on the lesson entitled "Science \& Technology" was implemented in the classroom. In general, there were three phases taking place in the instructional process.

\section{Phase 1 (Reading \& Vocabulary Focus)}

In this stage of teaching, the teacher asked students to read textbook about Science \& Technology individually. The students then were asked to find unfamiliar or unknown words in the text. Once it was done, the teacher pointed a student randomly until everyone gets his or her turn to come forward to write one unfamiliar word on the blackboard. Following this, the teacher asked learners to open their dictionary and look at the meaning of the vocabularies written on the blackboard. After this, students were pointed out in a random way to come forward, and to write down the meaning just next to the English words. The teacher, then, loudly pronounced the words from three to five times until he felt that 
the students had perfect pronunciation, and chose one student to translate it into Bahasa Indonesia.

\section{Step 2 (Translation and Reading Comprehension)}

The following learning activity was translation and reading comprehension. Teacher, in this stage of teaching, asked class to translate text of Science \& Technology into Bahasa Indonesia. Students were strongly encouraged to use English-Indonesian dictionary to help them complete the task. In the next 20 minutes, teacher asked the students who had finished the work to hand it over their work for marking. Following this, the learners were asked to answer twenty-five questions based on Science \& Technology text located just under the text. The questions comprised of 20 multiple choice questions and 5 open ended questions. Students who had finished answering the questions can first submit their work to be graded.

\section{Step 3 (Grammar Focus)}

After completing vocabulary exercise, translation and reading comprehension, the teacher continued to grammar session. He explained all grammatical rules in native language. In this part, he asked the learners to memorize the formula of simple present tense and simple future tense. After 15 minute of memorization the students were told to work in pairs to find out 5 sentences of both tenses in the text Science \& Technology, as well as decide the subject, predicate, object and adverb of the sentences. After that, the teacher called the representative to write sentence for each tense on the blackboard. Those students who had the same sentences as written on the blackboard were not compulsory to come forward. The teacher, then, made correction while providing the reasons for the right and wrong answers. Once it was done, the students were instructed to work individually to write 10 sentences, consisting of 5 sentences for simple present tense and 5 sentences for simple future tense together with their meaning.

From the teaching practice mentioned above, it is apparent that the teaching approach generally employed is GrammarTranslation Method (GTM), although there is a teaching technique associated with other approach, that is, Audio-Lingual. Let us 
thoroughly review the principles and techniques associated with GTM in the above-mentioned pedagogical practice.

In the first phase of the teaching process, the teacher delivered a lesson on Science and Technology taken from textbook. The use of this text was aimed at increasing students' ability in comprehending various foreign literatures, absorbing new knowledge within the text, as well as increasing students' reading skill. This is one of the most common tenets of GTM-based methods. The ultimate goal of traditional method is enabling students to comprehend English literatures (Larsen-Freeman and Anderson, 2011). Similarly, studying foreign language is purposefully designed to develop cognitive aspect and mental discipline of the learners (Richards and Rodgers, 2014). Also, as Brown (2007) points out, GTM is primarily used for the purpose of being scholarly and attain high reading proficiency in a foreign language.

In terms of teaching techniques used, the students were instructed to find new words together with their meaning and memorize them. This is one of typical learning activities in GTM. New vocabularies are taken from the text, and are learned through, dual vocabulary list, dictionary and memorization (Richards \& Rodgers, 2014). Likewise, Prator and Celce-Murcia (1979) as cited in Brown, (2007) claim that much vocabulary is taught through vocabulary lists both in the target language and mother tongue.

Apart from the use of GTM, the teacher also deployed Audio-Lingual Method. Pronunciation drill followed by students does reflect the Audio-Lingual Method. With regard to this, Yule (2014) points out that the Audio-Lingual method provides systemic and gradual teaching procedure by means of drilling. Lightbown and Spada (2013) also state that repetition and formation of habit are two strategies adopted in Audio-Lingual method.

Moving to the second stage of the teaching practice, the learners were told to do translation. This kind of learning activity does reflect the feature of grammar-based approach. The principle 
purpose of GTM is to enable the learners to attain high translation skill, and it is considered the most important factor for being successful language learners (Larsen-Freeman and Anderson, 2011). To attain the skill, translation from L2 to L1 is most prevalent task in the method. It is stated that translating sentences from target language into mother tongue is a frequent exercise in the classical method (Celce-Murcia, 1979 cited in Brown, 2007). Similarly, Harmer (2007) points out that sentences generated from grammatical rules are transferred into learners' L1 or vice-versa. All these pedagogical tasks were obvious when students were instructed to translate from single word to the whole text during the teaching process.

Students also answered the questions based on the reading text. This fits to one of the teaching techniques of GTM as stated by Larsen-Freeman and Anderson (2011), namely Reading Comprehension Questions. In this learning activity, students are told to answer the question based on students' understanding of the reading passage provided.

In the last stage of the teaching process, teacher deductively taught grammar rules with L1 explanation. The emphasis of deductive learning of grammar was intended to enable learners to produce sentences from a pattern, and this was of paramount importance skill to concentrate on. In relation to this, LarsenFreeman and Anderson (2011) argue for the importance of being aware of syntactic rules in grammar-based L2 learning. Long and explicit grammatical explanations were presented in the method (Prator and Celce-Murcia, 1979, as cited in Brown, 2007). The notion of using L1 as an instructional language is another principle of GTM, intending to enable learners to compare between their L1 and L2 (Richards and Rodgers, 2014). All these distinctive features can be seen from classroom activity in Science \& Technology, in which students were told to find and generate sentences based on the formula given.

\section{EVALUATION OF PRACTICE}


This section focuses on thoroughly evaluating both the benefits and drawbacks of the use of GTM in the Science \& Technology. Although such a grammar focused instruction has some benefits, it also has several constrains. The first and foremost benefit of applying GTM lies in the opportunity for the students to expand their general knowledge. Given literary work as the main resource used in the classroom, it then enabled the learners to engage with a wide variety of reading texts, ranging from education, economy, politics, population, science and technology, and thereby broadening their horizon. Also, the use of a variety of genres with different topics has not only increased the students' general knowledge, but also has enriched their lexical resource, which later can be of much help to develop communicative competence.

Another advantage of deploying GTM is the fact that it can be more efficient for the teacher to manage the class. As the method makes few demand on teachers since it is solely used reading text with no communicative competence required (Richards and Rodgers, 2014), teachers are more focused and can make good use of their time preparing a good lesson plan. Consequently, the teacher looked confident, and resulted in maximally achieving the goals and objectives of the instruction.

Finally, the use of the GTM has helped the students to have a quick and an in-depth understanding of the lesson. In the grammar-based method, teacher used native language as a medium of instruction (Prator and Celce-Murcia, 1979, as cited in Brown, 2007). This has positively increased student's comprehension, and reduced their pressure, as well as confusion since there was no language barrier inhibiting them in the classroom interaction. The use of L1 in classroom also enabled the learners to ask a question and/or for clarification with ease, and thus promoting positive learning experience as a whole.

Despite the benefits mentioned above, the adoption of GTM also has two fundamental weaknesses. Students' affective domain was entirely neglected. As students tend to work individually, there was less opportunity for them to work in pairs or 
group. Virtually, all learning activities were done individually with a textbook and teacher as main learning resources. In addition, the teacher seemed to ignore the feeling of his students. There was no extra or special attention to those who have difficulties during the class as completing material was a legitimate target.

Another weakness relates to the limitation of teacher's creativity. The instructor merely followed and focused on material and learning activities found in the textbook. There was no such modification and adjustment that can make the learning more engaging, fun and meaningful for the students. Textbook provided by the government was the only resource used, and completing all learning activities was the overarching goal of the instruction. This approach has resulted in monotonous and static way of teaching.

\section{SUGGESTED REFINEMENT}

Based on the weaknesses of the GTM implementation mentioned above, here are two suggestions as a conclusion, to make the learning experience be more interactive, engaging and meaningful.

Firstly, apart from individual work, pair and group work should be incorporated. In relation to the importance of group work, Harmer (1998) argues that it can provide equal opportunities for students in classroom participation and have more chance to immerse in the target language compared to a whole-class management. Although GTM focus on two skills (reading and writing), but this does not necessarily inhibit students from working collaboratively. As Long (1977) says, group work can be implemented in four language skills, and even combination of them. He, however, suggests that it should be wisely applied in that other teaching techniques could be better. More importantly, students who successfully engage in language learning can boost their motivation (Dörnyei, 2009), one of the best ways to encourage student's engagement is through group work.

Secondly, teacher should not make textbook as a legitimate resource for the learning process. In other words, he must be 
creative in adapting as well as modifying the core resource. The course contents and examples of prescribed textbook tent to portray urban life or experiences, like in Jakarta where it was written and published. Students in rural place might find it challenged to comprehend the content as not reflecting their life. Bax (2003) reminds us the importance of context where the instruction takes place.

It is acknowledged that the teacher did not have sufficient to time to make his own resource. Nor did he have exceptional ability to write one. However, this does not mean that he deliberately used the teaching recourse as it is, and neglecting its appropriateness. It is worth noting that "the difference between writing a text-book and teaching from a textbook is that once a textbook is written, it is fixed, whereas when you teach with it, you can make changes in how you use it (Graves, 2000 p.173). Similarly, Grant (1988) suggest three alternatives when a teacher find inappropriate textbook, either to omit, replace or add it. Therefore, sense of selectivity and flexibility of using learning resource are key to promoting an effective and meaningful teaching and learning experience.

\section{REFERENCES}

Bax, S. (2003). The end of CLT: A context approach to language teaching. ELT Journal, 57 (3), 278-287. Retrieved from https://doi.org/10.1093/elt/57.3.278

Brown. H. D. (2007). Teaching by principles: An integrative approach to language pedagogy ( $3^{\text {rd }}$ ed). While: Pearson Education.

Dörnyei, Z. (2009). The L2 Motivational Self System. In Dörnyei, Z \& Ushioda, E (Eds) (2009) Motivation, language identity and the L2 self.,pp. 9-42. Bristol: Multilingual Matters.

Graves, K. (2000). Designing language courses: A guide for teachers. Boston: Heinle \& Heinle.

Grant, N. (1987). Making the most of your textbook. London: Longman

Harmer, J. (2007). The practice of english language teaching (4th ed). Harlow: Pearson Education Limited. 
Harmer, J. (1998). How to teach english: An introduction to the practice of english language teaching. Harlow: Pearson Education Limited

Larsen-Freeman, D., \& Anderson, M. (2011). Techniques \& Principles in Language Teaching. Oxford: Oxford University Press.

Lightbown, P.M., \& Spada, N. (2013). How languages are learned (4th ed.) Oxford: Oxford University Press.

Long, M. H. (1977). Group work in the teaching and learning of english as a foreign language-problems and potential. ELT Journal, 31(4), 285-292. Retrieved from https://doi.org/10.1093/elt/XXXI.4.285

Richards, J. C \& Rodgers, T. S. (2014) Approaches and methods in language teaching (3rd ed). Cambridge: Cambridge University Press.

Yule, G. (2014). The study of language (5th ed). Cambridge: Cambridge University Press. 